\title{
Implications of Environmental Pollutions on Ethiopian Fisheries: Review Study
}

\author{
Hayelom Berhe Dagnaw ${ }^{1} \quad$ Eyob Bezabeh Kidane ${ }^{2}$ \\ 1.Ethiopian Institute of Agricultural Research,NationalFishery and Aquatic Life Research Center, Sebeta, Addis \\ Ababa,Ethiopia, P.O. Box, 64, Sebeta, Food Science and Nutrition \\ 2.Ethiopian Institute of Agricultural Research, National Fishery and Aquatic Life Research Center, Sebeta, \\ Addis Ababa, Ethiopia, P.O. Box, 64, Sebeta, Agricultural Economics
}

\begin{abstract}
The objective of this review article was to summarize the current impacts and its implications of environmental pollution on the fisheries sector in Ethiopian fisheries. The materials for this review were kinds of literature (published and unpublished) including internet access and personal experiences were used for the source to obtain applicable data. Ethiopia has a potential source of water used for fisheries and irrigation-based agriculture. The Ethiopian Rift Valley is one of the potential sources used for fisheries purposes and it is also the most environmentally vulnerable water source in the country. Climate changes and environmental pollutions affect the fisheries and aquaculture sector directly by influencing the fish stocks and the comprehensive supply of fish for consumption. In Ethiopia, environmental pollutions are significantly affected the fisheries sector, especially in the Rift valley areas which come from different sources. $92.8 \%$ of the liquid sewages released from Addis Ababa city enter into rivers and rain-water channels having a chain with Lakes along with the downstream with above the maximum permissible levels of BOD and COD. And, applications of commercial agricultural fertilizers including pesticides and floriculture significantly affected the water qualities of Ethiopian water bodies especially the central Rift Valley lakes and, currently, the affluence and availabilities including the fish quality and the ecosystem services under the down streams are found at risk. The accumulation of nutrients affects biodiversity and fisheries. Under Rift valley lakes, $73 \%$ of the fish landing is sold nearby markets and the consumption of fish that are contaminated through different concentrations of heavy metals above permissible levels is going to be toxic for human beings. Therefore, the government and respective bodies should give more emphasis on the mitigations and management's especially with agricultural, floriculture, and urbanization related waste entered into the water bodies; affects the ecosystem and the fishery sector in the country.
\end{abstract}

Keywords: Environment, pollution, climate change, fisheries, water bodies, Ethiopia

DOI: $10.7176 /$ RHSS/11-17-02

Publication date:September $30^{\text {th }} 2021$

\section{Introduction}

\subsection{Background}

Ethiopia is the country having a huge water source form African countries and it is endowed with inland aquatic ecosystem such lentic and lotic water bodies (Awoke, 2015; Utaile and Sulaiman, 2016), Awulachew et al. 2007). In Ethiopia there are 12 water bodies with 122 billion $\mathrm{m}^{3}$ annual flow (Awulachew et al., 2007)having a total length of $8065 \mathrm{~km}$. However, Ethiopia has huge source of water bodies such as many lakes and reservoirs and small water bodies covering a total surface area of $13,637 \mathrm{~km}^{2}$. In the country, fish comes from inland water bodies and its fish production potential estimated 94, 500 tonnes annually(Tesfaye and Wolff, 2014).

According (Janko, 2013, 2014), it was explain that the main source of fish and fish products to the country were lakes, reservoirs, rivers and they have been supported by the data from Minster of Agriculture (MOA). From the data we considered that $99.9 \%$ of fish comes to the market from the aforementioned water bodies and the contribution of the aquaculture is insignificant and the constraint also merely infant (Hayelom and Eyob 2020).This indicated that, Ministry of Agriculture (MOA) considered the fishery sub-sector as the potential intervention areas to achieve the objective of enhancing food security, employment, and provide alternative source of income to improve the livelihood of the rural peoples in sustainable manner.

Now day water pollution is a universal problem and it requests critical considerations (Abrehet et al., 2015; Ali et al., 2008).However, looking of aquatic ecosystems through protection and re-establishmentof involvements has not been given enough attention (Baron et al. 2002; Ansara-Ross et al. 2012).In addition to uncontrolled and muddled system on capture fishery, environmental pollution also another critical problem that exists naturally or anthropogenic ways. Due to the limitations of waste water and industrial swages including floriculture effluents introduced into the streams and rivers currently affected the water quality which is used for aquaculture system in the Ethiopia.Off the water source of the country, to the extreme level, Lakes under the Rift valley areas are highly susceptible to different source of pollutions which are raised due to expositions of cities and industrial swages effluent into the water bodies.Different studies testified that Rift valley Lakes are under extreme treat and which are polluted by trace elements wastedout from different industries and agricultural practices. Therefore, 
discharging of domestic waste-water from food or wood and other industries have significant source of pollution via livestock farming including silage production or manure spreading on land. This input of organic matter in to the aquatic environment can use huge amount of oxygen, having the potential of killing fish and disturbing of the aquatic ecosystem; which provides the function of variability of natural process and transformation of toxin (The handbook for management and restoration of aquatic ecosystems, 2015).In addition to this, massive land use and discharges of untreated urban, industrial wastes including excessive uses of agricultural chemicals affected the quality of natural water bodies and causesvarious toxic effects on the aquatic biota(Ali et al., 2008, Beyene et al. 2009; Ansara-Ross et al. 2012; Abong'o et al. 2015; Teklu et al. 2016); which leads to harm the capacity of ecosystems and cause a downside to deliver the anticipated services (Maltby et al. 2018), which revealed, the agricultural chemicals significantly affected the aquatic ecosystem through that pesticide affected to fish. This indicated that, the studies concluded that, that aquatic lives including fish are affected due to the alteration of water quality.

From Rift valley Lakes, Lake Ziway is one of the very imperative fishery land site in the country, but the water quality of the Lake is beyond the guidelines used for dirking water (Bekele and Hussien, 2015), and the fishery of the lake is found under threat and its annual yield fish is declined(Hirpo, 2016, Abera, 2018), this indicated that in Lake Ziway, with increasing the level of nutrient then the water level will be decreased, and this leads for the changes of composition in the Lake. On the other hand, the Ethiopian urbanization is expanded especially around Addis Ababa which has chains with the streams that going to be introduced in to the streams of central Rift valley. This chain connected with lakes, streams under Rift valley areas which is use for hydrological and ecosystem features (Estifanos KT, 2008). In addition to the Rift Valley, the water characteristics of Lake Tana also affected due to human and natural processes. This indicated that the water under Lake Tana is significantly affected by different waste indicators including organic pollutions (Goraw et al., 2017) and, the author concluded that sedimentation, fecal pollution, and wetland encroachment can be used for water quality management in Lake Tana.

In general, in Ethiopia, thewater bodies under the central Ethiopian Rift valley area areto the extreme and the most susceptible environments for climate changes which lead to environmental pollutions. Currently, there are limitations of information on the effects of environmental pollution including effects of urbanizations, invasive weeds and irrigation practices associated with banded agricultural chemicals, and floricultures on Ethiopian fisheries. Therefore, the aim of this review paper is to document the current status,provide compiled information and their mitigation directionson Ethiopian water bodies used for fisheries sub-sectors.

\section{Methodology}

For this review, different source of literatures, journal articles, books, workshop documents, and proceedings including pollution based climate change and ecosystem studied in different lakes, mitigation of regional and local world and personal experiences and observations. It includes also FAO reports such as water pollutions from agriculture, and research articles on organochlorine pesticide and heavy metal contaminations associated with bioaccumulation in fish bods, Ethiopian policy on environmental and climate changes, impacts of climate change on fisheries and aquaculture, chemical pollutants and ecological system, climate change and water quality problems and their mitigations, urbanization in Ethiopia and environmental impacts on reservoirs as general. And additional to this, the sources were gathered from unpublished M.Sc. thesis and $\mathrm{PhD}$ dissertations, and documents were gathered from internet access, research institutions and individual researchers.

\subsection{Environmental pollution}

According to U.K. Environment Protection Act., 1990, the term pollution is defined as the release into any environmental medium from any process of substances which are capable of causing harm to man or other living organisms of substances by the environment (Ramamohana R. et al., 2017).It is the addition of pollutants into the ordinary environment which disrupts natural resources and humans. It is undesirable changes which may bring due to chemical, physical and biological characteristics of the soil, water and air having health problem to all living things and negative effects on the ecosystem as general, including flora and fauna.However, pollutants are classified as degradable or non-persistent pollutants such as domestic wastes and sewages, on the other hand, slowly persistent pollutants, remains for a very long period of time such as pesticides, fungicides and herbicides; while, non-degradable pollutants are pollutants which are never degraded by natural process such as toxic elements like lead and mercury.

With concepts of environmental pollutions, among the main source of pollutants which disrupted of the qualitiesof water bodies includes urbanizations and succeeding of human settlements around the Lake basins. The pollutants which leads to changes in physical, chemical and biological changes of the lakes which becomes as the main causes for suffering fisheries and functions of the whole aquatic ecosystem (Zinabu et al., 2002). 


\subsection{Fisheries}

In Ethiopia, the artisanal freshwater fishery is one of the most important economic activities and it uses as alternative means for achieving food security and poverty reduction (Kebede et al., 2017, Dereje T., 2014). However, the benefits gained from fisheries development have positive impacts, but the aquaculture sector is in the infancy stage and its contribution is limited as compared with the fishery sub-sector (Hayelom and Eyob, 2021). The fishery is defined commonly as system collections of three interacting components: the aquatic biota, the aquatic habitat, and the human users of renewable natural resources. Each of these components influences the fishery's performance. Knowing the whole scheme or method used for better management is very important in fishery industries. There are many different types of fisheries and are classified in several ways: (i) types of environment (freshwater habitats-like reservoirs, rivers, streams, and ponds; saltwater habitats- estuarine, coastal, open ocean), (ii) method of harvest (seining, trolling, trawling, fly casting, separating, and dip netting). (ii) types of access permitted (open access to fishing, open access with regulation, limited or purchased access, and private property),(iv) organism of concern (salmon, shrimp, bases, turtles, squid, cod, sharks, sea horses, whales, and swordfish), (v) purpose of fishing (commercial fishing for product to sell, subsistence fishing for direct food consumption, or recreational fishing for sport and leisure), (vi) degree of fishing wildness of the target animals (totally wild and free-roaming animals, totally captive animals, but released in the wild to be captured when they mature)(Lackey, Robert T., 2005).

Fish farming has been practiced in Ethiopia. Ethiopian fisheries production is focused in water bodies of Rift Valley areas and Lake Tana which targeted Clarias gariepinus, Cyprinus Carpio and Carassius, and Oreochromis niloticus. Not only the limited access and the production status associated productions under-exploited, fish contamination, fish spoilage, and unhygienic handling and processing at the landing sites are also the major constraints that affect the fishery trades in all water bodies and it leads to environmental pollutions in the country. In addition to this, fish post-harvest loses which accounts (30-40\%) from the total harvest under Rift Valley areas (Yared Tigabu, 2010, 2013); and the climate change becomes the main challenge for fisheries in sub-Sharan Africa, and even it increases its impact in the world. The rise in carbon dioxide emission and the successive rise of temperature triggered several damages including excessive rainfall and flooding in some areas and complete drying of rivers and lakes in Africa. The effect of climate change is more noticeable in poor sub-Saharan Africa including Ethiopia, and it affects the aquatic water bodies including rivers and lakes. The temperature rises lower the level of lakes and reservoirs due to increments of evaporation which affects the inflow rate into lakes.

Climate-stimulated changes to resource flow can basically affect the viability of livelihood of the poor societies (SEI, IUCN, IISD, 2003). Climate change may indulgence certain species over others (Arntz WE et al., 2006) and thereby change the biogeography of fish stocks and their relative abundance (Cheung WWL et al., 2008). This indicated that communities are significantly impacted by climate change and environmental pollutions. The sea-level rise and extreme events such as storm surges can lower the availability and the quality of freshwater sources to fishing communities(Bridges KW et al., 2009), this showed that the variabilities of the weather including storm and flood frequency affects the physical capital households of the entire communities and this causes the harvesting capacity on the fishing communities. In general, due to these variabilities, the catches going to decrease and this diverts in food availability and food affordability and brings the risk of malnutrition and undernutrition for communities greatly depends on fish as a source of protein (Ogutu-Ohwayo R et al., 1997). These changes can affect the natural capital, and income, and harvest costs of the fish.

\subsection{Climate changes and fisheries in Ethiopia}

Climate change is the long-term fluctuations and change of weather in which it has contributed directly or indirectly to human activities. Climate change has the capacity to influence the composition of the globe including the regional atmosphere which causes public health problems, agricultural practices, food security, industry, resource of water bodies, biodiversity and shoreline areas. Data on Climate change developed from Ethiopia using historical data of temperature and rainfall from 1971 to 2000 of selected areas in the country indicated, that there is a variation of rainfall from year to year for the period of 1951 to 2005 over the country (National Meteorological Agency, NMA,2007). Climate changes in Ethiopia are changed and varied and characterized by rainfall and increasing trends in temperature; and this becomes a major cause of environmental pollutions and differences within regions (National Metrological Agency, 2001).Temperature increment in the country is rapid during June, August, and September with the rate of $0.320 .32^{\circ} \mathrm{C}$ per decade (McSweeney et al, 2010); and the country is highly susceptible to this variability, and this also causes rainfall variabilities. At the global level; fossil fuels are the main source of greenhouse gasses for climate change and environmental pollutions, and agricultural systems especially incorporations of agricultural pesticides are a source of poison chemicals(Yohannes and Mebratu, 2009, EdwardsJones et al, 2009). In Ethiopia, the agricultural system is also a source of greenhouse gas emissions which is $51 \%$ of the total emissions in the country (UNDP Ethiopia, 2011). Thus; in the country, there is increasing of using pesticide especially in floriculture, which is currently expanded in Ethiopia have a significant effect on environmental pollutions and disturbances of water qualities downstream. And, the effluents of these chemicals 
which are long-term persistence are introduced into the dawn-stream, Rift valley areas of water bodies have significant effects on climate change caused significant effects on the environment and different sectors such as water bodies, agriculture, and food security, human health, ecosystem and biodiversity. Climate change affected the fisheries and aquaculture sectors directly employing the fish stocks and the comprehensive supply of fish for consumption.

Climate change may affect the production of fisheries and aquaculture in which sea surface temperature changes become a driving force that affects the algal flowers; less dissolved oxygen, increase the occurrence of disease, changed the local ecosystems, and this creates variations in hunters and invasive species and plankton structures. And, this biophysical affects aquaculture and fisheries; that for capture fisheries associated with climate changes have impacts on the wealth and species composition of the fish stock. On the other hand; the biophysical changes may affect the change in timing and success of migrations, spawning, and peak abundance, as well as in sex ratio; and this has effects on the potential loss of species or composition variations in capture fisheries (World fish center, 2007).

However, El Niño-Southernoscillationis also the main cause for climate changes; which causes the instabilities of the setting and timing of ocean currents and outburst alters nutrient supply in surface water and, thus primary productivity. And, this changes the distribution and productivity of open sea fisheries. However, the El Niño-Southern changes ocean temperature and bleached coral, and this condensed productivity of reef fisheries (World fish center, 2007). The higher inland water temperatures may diminish the availability of wild fish stocks by harming water quality, deteriorating dry season mortality, bringing new predators and pathogens, and changing the abundance of food available to fishery species. The problem of climate change affects the aquatic water bodies mainly rivers and lakes. The rise of temperature increases the rate of evaporation and declined the inflow rate into lakes which in turn lowers the level of lakes and reservoirs. The shoreline areas which are the breeding and feeding ground of juvenile fish affected easily and this going to be reduced the new fish enrollment of the stock and the annual fish yield. Aschalew et al (2018), reported from their assessments of lake Koka, they observed that, there are radical reductions of the reservoir which have not been observed over a decade. And, this oscillation of the lake water level is believed to be due to El Niño brought about by climate change.

\subsection{Environmental pollution associated with Ethiopian water bodies}

Water pollution is an addition of certain substances for example organic, inorganic, and biological substances having the capacity to making the water unhealthy for use and reduces its quality. The basic source of water pollution includes a point source, which pointed out toward the water bodies from the origin of where pollution has existed. And the non-point source indicated that, having different sources and is difficult to regulate such as sewages from industries, and agricultural practices.

Ethiopia has a number of lakes and rivers used as a potential source of fisheries, electrical dames, and different agricultural irrigation practices. Of these different water sources in the country, the Ethiopian Rift Valley is one of the Great East African Rift Valleys and the central Rift Valley is one the most environmentally venerable water source in the country. Thus, water pollution is a universal encounter that has increased in both developed and developing countries, affects economic growth as well as the physical and environmental health of billions of people.

However, the country has diversified in the geographical system and landscapes which varied and range from peaks of 4,550 $\mathrm{m}$ above sea level to a low depression of $110 \mathrm{~m}$ below sea level. Therefore, this variable landscape with water sources makes it most susceptible to pollution.

When we see Lake Ziway, the primary source of pollution is the recently enormous flower industries that are constructed around Addis Ababa, mainly Lake Ziway and upper Awash Valley (Gudeta, 2012).In addition to this; agricultural activities such as horticultural farms practiced near the Lake are also the major sources of pollution. Chemicals used by horticultural farmers and floriculture companies' include pesticides, chemical fertilizers, plant growth hormones, and flower preservatives are significantly affect the water quality of Lakes and indirectly disturbs the aquatic system of the water body (Jansen and Harmsen, 2011). A study reported that near Lake Ziway found 30 pesticides having the concentration of $0.1 \mu \mathrm{g} / \mathrm{L}$ out of which five are categorized as having high human risk (Jansen and Harmsen, 2011)and these pesticides are banned chemicals in European societies (Keith, 1991), but still under practiced in Ethiopian agricultural system.

\subsection{Causes of environmental pollution for Ethiopian water bodies}

Though the country is rich in water sources and its fish production potential yield is 94,500 tons/year (Tesfaye and Wolf, 2014), but due to globalization, the water source especially the lakes of Rift valley areas going to be under stress. Today urbanizations including industries such as textile and tanneries, floriculture industry, irrigations using agrochemicals, invasive weeds and fishing methods and types of fishing are the main factors that cause rift valley lakes going to be under stress for fisheries system. These industrial wastes and long-term persistent chemicals are introduced into the Rift valley Lakes and the aquatic ecosystems. 
In developing countries, such as Ethiopia urbanization is increasing alarmingly. Addis Ababa, the capital of Ethiopia is located at the edge of East Africa Rift Valley. Currently, the pollution is increased in the city, while the sanitation and wastewater infrastructure has not kept step with population and the urbanization growth (CSA, 2007).In addition to this; there are a large number of industries whose untreated wastewater is discharged into the small river network. In 2010 there were 887 large and medium industries were operating in the capital city of Ethiopia, Addis Ababa, and most of these industries are located in the area of Akaki River which is flowing towards farm which is used for irrigation purposes (CSA, 2013) and causing the challenge to surface water quality deterioration(Alemayehu, 2006).In addition to the exposure of toxic elements while industrial effluents are also used for irrigation purposes, the depository of all industrial effluents in Addis Ababa city is the aquatic environment and it becomes the main encounter for aquatic species such as fish. The study reported (Melaku et al., 2004), the surface water quality of the Akaki river was suitable for irrigation purposes, while now day the potentially toxic elements are arising from the aquatic ecosystem increased from urban industrial development and these metals are stored in the soil and food chain (Mekonnen et al., 2014)and these heavy metals which exceeded from the Ethiopian permissible level (European Community and WHO for drinking water quality) going to be leaching into Lakes (Aschale et. al., 2016).

\subsection{Heavy metal bioaccumulation and challenges of Ethiopian fisheries}

With changing environmental conditions under increasing anthropogenic influences, the nature of the Ethiopian Rift Valley Lakes is also changing. Untreated wastes discharged from different sources are contaminated of urban, agrarian and may enter the food chain, accumulate in organisms, and this going to affect their existences in different water bodies in the country. Nowadays, the wealth and availability including the fish quality and the ecosystem services of Rift valley lakes are found at risk. The consumption of fish that are contaminated through different concentrations of heavy metals is going to be toxic for human beings (Castro-González and MéndezArmenta, 2008). Under the Ethiopian Rift valley, there are a number of lakes and highly productive native fish species; $73 \%$ of the fish landings are sold in nearby markets (Ayenewand Legesse, 2007, FAO, 2011).In addition to factors affecting the fisheries sector, environmental pollution, which leads to climate change; its contributions to food security and nutrition are not visible in Ethiopia. And the fish production depends almost on small-scale artisanal fisheries, and due to poor handling, transportation, and climate change; the fish is found of poor quality(Hayelom B. and Eyob B., 2021).

However, heavy metals are naturally traced amounts and their concentrations statuses are may bring from geological weathering of rocks and soils and manmade practices such as irrigation and using of agrochemicals (Tüzen, 2003; Ali et al., 2011); and the concentration of heavy metal are higher as compared with the mountainous areas as compared with the remote o mountainous areas. A study reported that heavy metals from point and nonpoint sources damaged water systems, and this going to cause tissues or special organs deformation in fish (Henry et al., 2004).

However, both Lake Awassa and Lake Koka are affected by different industrial discharges. And a study reported that; the accumulations of mercury were very high in different fish body parts, especially the fish liver, and this indicated that; the tendency of mercury bioaccumulation is high than other trace metals (Mesfin M.T. et al., 2012). Therefore, different studies reported that, waste discharges into the Ethiopian water bodies, especially under Rift valley areas have significant increments of the heavy metal accumulations in fish and water samples (Table 1and 2). 
Table: Levels of heavy metal concentration of water sample from different Lakes in Ethiopia

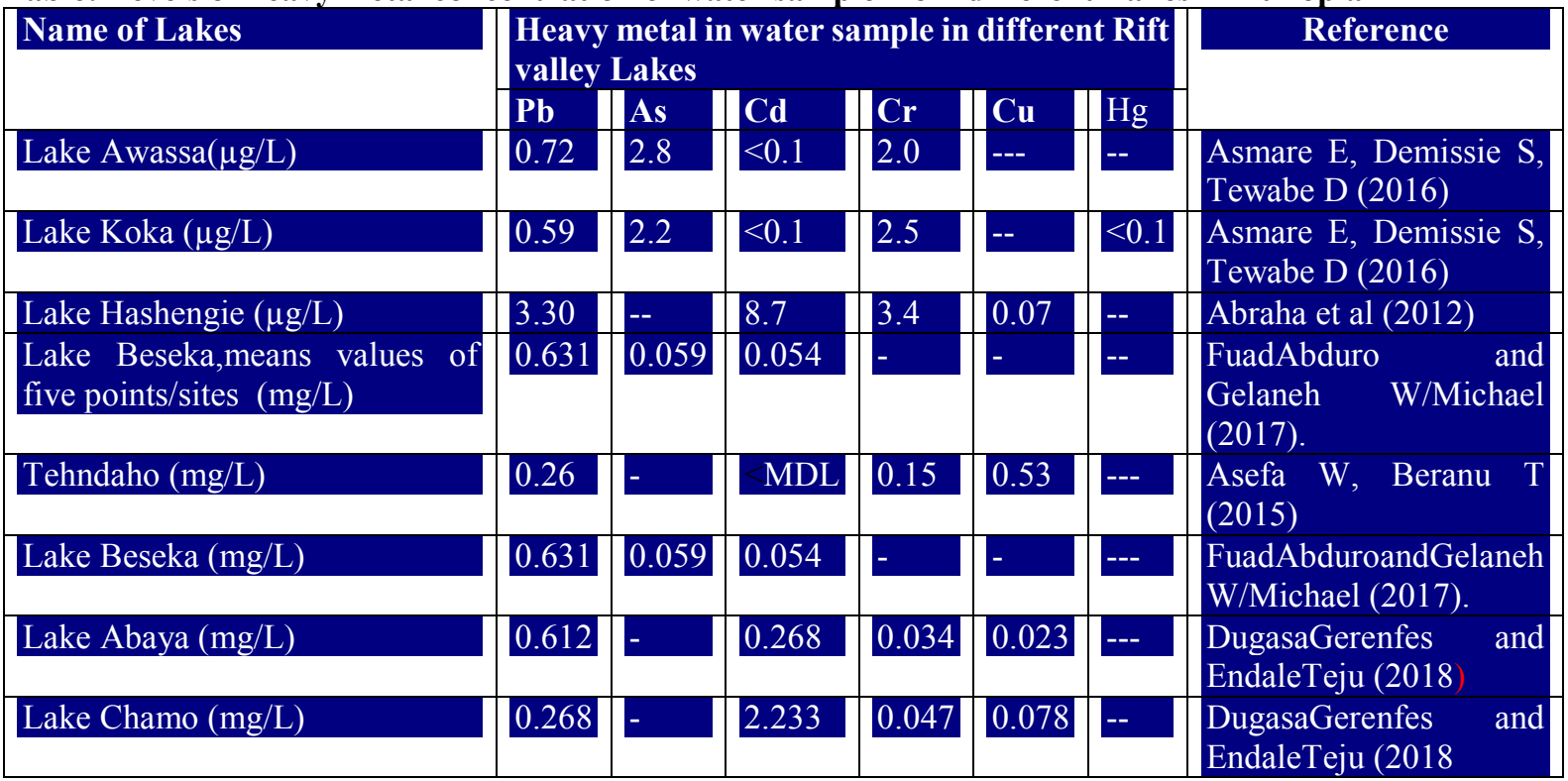

*MDL: Maximum detection limit

Table 2. Levels of heavy metal accumulation of fish samples (liver) from different Ethiopian Lakes

\begin{tabular}{|c|c|c|c|c|c|c|c|c|}
\hline Lake & Fish part (Liver) & Heavy & metal & in fish & ample & & & Reference \\
\hline & & $\mathbf{P b}$ & & $\mathbf{C d}$ & $\mathrm{Cr}$ & $\mathbf{C u}$ & $\mathrm{Hg}$ & \\
\hline $\begin{array}{ll}\text { Lake } & \text { Abaya } \\
(\mathrm{mg} / \mathrm{kg}) & \\
\end{array}$ & Tilapia & 1.63 & & 0.027 & 0.038 & 0029 & & 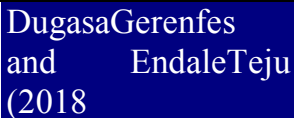 \\
\hline & Barbus & 0.130 & - & 0.017 & 0.038 & 0.044 & --- & 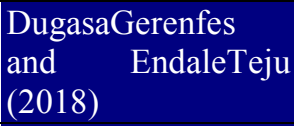 \\
\hline $\begin{array}{ll}\text { Lake } & \text { Awassa } \\
(\mu \mathrm{g} / \mathrm{g}) & \end{array}$ & Tilapia & 0.080 & - & 0.180 & 0.250 & 219.68 & --- & Yared et al (2013) \\
\hline $\begin{array}{l}\text { Lake Awassa } \\
\text { town }(\mu \mathrm{g} / \mathrm{kg})\end{array}$ & $\begin{array}{l}\text { Tilapia } \\
\text { niloticus) }\end{array}$ & 24.6 & 291 & 416 & 1622 & -- & 89. & Larissa et al (2012) \\
\hline & C. gariepinus & 69.3 & 380 & 165 & 1330 & -- & 140.0 & Larissa et al (2012) \\
\hline $\begin{array}{ll}\begin{array}{l}\text { Lake } \\
(\mu \mathrm{g} / \mathrm{kg})\end{array} & \text { Koka } \\
\end{array}$ & $\begin{array}{l}\text { Tilapia } \\
\text { niloticus) }\end{array}$ & 121 & 159 & 1156 & 1559 & -- & 511 & Larissa et al (2012) \\
\hline & C. gariepinus & 241 & 241 & 450 & 210 & -- & 242 & Larissa et al (2012) \\
\hline $\begin{array}{l}\text { Lake Tehndaho } \\
(\mu \mathrm{g} / \mathrm{g})\end{array}$ & Tilapia & 2.45 & & 0.32 & 0.73 & 3.54 & & $\begin{array}{l}\text { Asefa W, Beranu T } \\
(2015)\end{array}$ \\
\hline & Cat fish & 3.42 & -- & 0.41 & 0.83 & 3.29 & -- & $\begin{array}{l}\text { Asefa W, Beranu T } \\
\text { (2015) }\end{array}$ \\
\hline Lake Hashengie & Tilapia & 1.24 & -- & 0.58 & & 0.85 & -- & Abraha et al (2012) \\
\hline & $\begin{array}{l}\text { Common } \\
\text { Carp(Cyrpinus } \\
\text { carpio) }\end{array}$ & 1.24 & -.- & 0.53 & 0.65 & 1.4 & -- & Abraha et al (2012) \\
\hline $\begin{array}{l}\text { Gilgel Gibe (I) } \\
(\mathrm{mg} / \mathrm{kg})\end{array}$ & $\begin{array}{l}\text { Tilapia(O. } \\
\text { niloticus) }\end{array}$ & 6.20 & -- & 0.36 & 18.31 & 8.28 & -- & \\
\hline & $\begin{array}{l}\text { Labeo Barbus (L. } \\
\text { infermendius) }\end{array}$ & 10.04 & -- & 0.53 & 19.53 & 11.21 & -- & \\
\hline
\end{tabular}

\section{Environmental pollutions associated with agricultural practices in Ethiopia}

Of the most common source of water, pollutions include agricultural practices, industries, and settlements used for human beings. Worldwide, 80 percent of wastewater from the urbanized one is squared into different water bodies, and heavy metals and toxic swages including deadly solvents released from different industries also discharged 
into it (WWAP, 2017). In addition to this, agriculture uses 70 percent of water and it releases wastes in terms of agrochemicals such as fertilizers and pesticides which contributes significant roles for water pollution in the world and this has effects on health problems and creates a hazard for aquatic ecosystems (UNEP, 2016). However, agricultural practices using different pesticides which going to be accumulated of nutrients in Lakes have impacts on biodiversity including fisheries, this may be that that the world devours more mineral fertilizers (FAO, 2016a).

Ethiopian agriculture is the backbone of the country's economy and it is the main source of income for the individual households in the country. However, agriculture is mainly focused on small-scale farmers, having low technological practices and this leads to low agricultural productivity in the country. Therefore, this low productiveness leads the government to encourage using of agrochemicals (CSA, 2012)and this was introduced since1960s. The use of agrochemicals such as pesticides increased and the farming mechanism is expanded mainly with the floriculture industry and this also has significant effects on the growth of the import of pesticides beyond 2400 tonnes annually (Assefa, 2010, PHRD, 2015).

However, manmade activities associated with the agricultural transformation are the source of pollutions in Africa and is vulnerable to the environment (Pretty et al. 2011). For example types and quantities of agrochemicals are increased in the Ethiopian agricultural system (Taddese and Asferachew, 2008) and this indicated that an application of pesticide leads to contamination and disruptions of aquatic systems in general (Jansen and Harmsen, 2011). Teklu B.M, et al. (2014) reported on his pesticides-crops combination study, which, indicated that the direct surface water intake is associated with low acute health risks for humans in Ethiopia. On the other hand, possible and high risks are estimated for aquatic organisms for some combinations; that the exposure toxicity ratios of some pesticides of atrazine, chlorothalonil, dimethoate, and endosulfan, have possible and high risks across the aquatic organisms of algae, Daphnia, and fish. Under Rift Valley areas such as Lake Ziway, there is an increase in the applications of pesticides and fertilizers for agricultural activities and huge horticultural practices. And (Berhan M. T et al., 2016), reported that $\mathrm{pH}$, Potassium and Iron, indicated that the values were above the maximum permissible limit level, above fifty percent for Ethiopian standard for dirking water. In addition to this, the increased volumes of untreated wastes and the decline of the outflow of water from Lake Ziway to Bulbula River can causes interruption of aquatic life such as fish mortality and pollution of water, reduce the quality of drinking water (Jansen and Harmsen, 2011).

\section{Urbanization on environmental pollution, fisheries and aquatic life in downstream}

Ethiopia is one of the least urbanized countries in the world, and its population (around 16 percent) is living in urban centers (PCC, 2008). Contaminations of ground and surface water are the most serious problems affecting the health of the population in Ethiopia. However, in the country, surface water pollution is realized as a serious problem for the communities yet. Wastewaters such as solid and liquid parts which are discharged in Addis Ababa city are directly related to the population growth and industrial expansion of the city. In Addis Ababa, there are a number of sources of pollutants that going be deteriorate the qualities of different sources of water. A study from Tamiru. et.al. revealed that the major source of pollution for developing countries includes industries, domestic and agriculture(Danquah L., 2010) and, UNESCO reported for Ethiopian national water development in 2004, 90 percent of industries in Addis Ababa have simply discharged their effluents into nearby bodies and streams without any treatments (Olson E., 2004).

The introduction of different organic pollutants from different sources such as industries and agricultural practices can cause organic enhancement (low level of oxygen) for the water bodies. And this declined availability of oxygen from the water bodies is the cause of the deaths of animal and plant species that are incapable to tolerate this lack of oxygen and, but invasion plant species such as water hyacinth which can tolerate the low level of oxygen can exist within the water bodies (Mekonnen and Amsalu., 2018). The excess concentration levels of nitrogen and phosphate compounds in the Shankila River in Addis Ababa showed that the study site was highly polluted and these concentrations were above the standard limit. Therefore, Eutrophication of the river existed in the river downstream and abnormal growth of phytoplankton and algae, and bloom algae harmed the aquatic life by clogging the gill of fish and produce a poison which can harm human health and wildlife (Mekonnen and Amsalu, 2018).

In addition to this, in Addis Ababa city, both solid and liquid wastes have as significant effects on environmental pollutions. In the city, the maximum coverage $(92.8 \%)$ of the liquid waste is disposed of inappropriately and it going to be mixed with river and rainwater channels(WSA, 2010). Benti et al (2016) reported that for selected industries in Addis Ababa, the concentrations of wastes of both Chemical Oxygen Demand (COD) and Biological Oxygen Demand (BOD) were significantly above the maximum permissible limit value in all divisions. Therefore, the author generalized that the levels of these chemical characteristics of both BOD and COD in Addis Ababa's selected industries increased as indicated in figure 1 given below. 


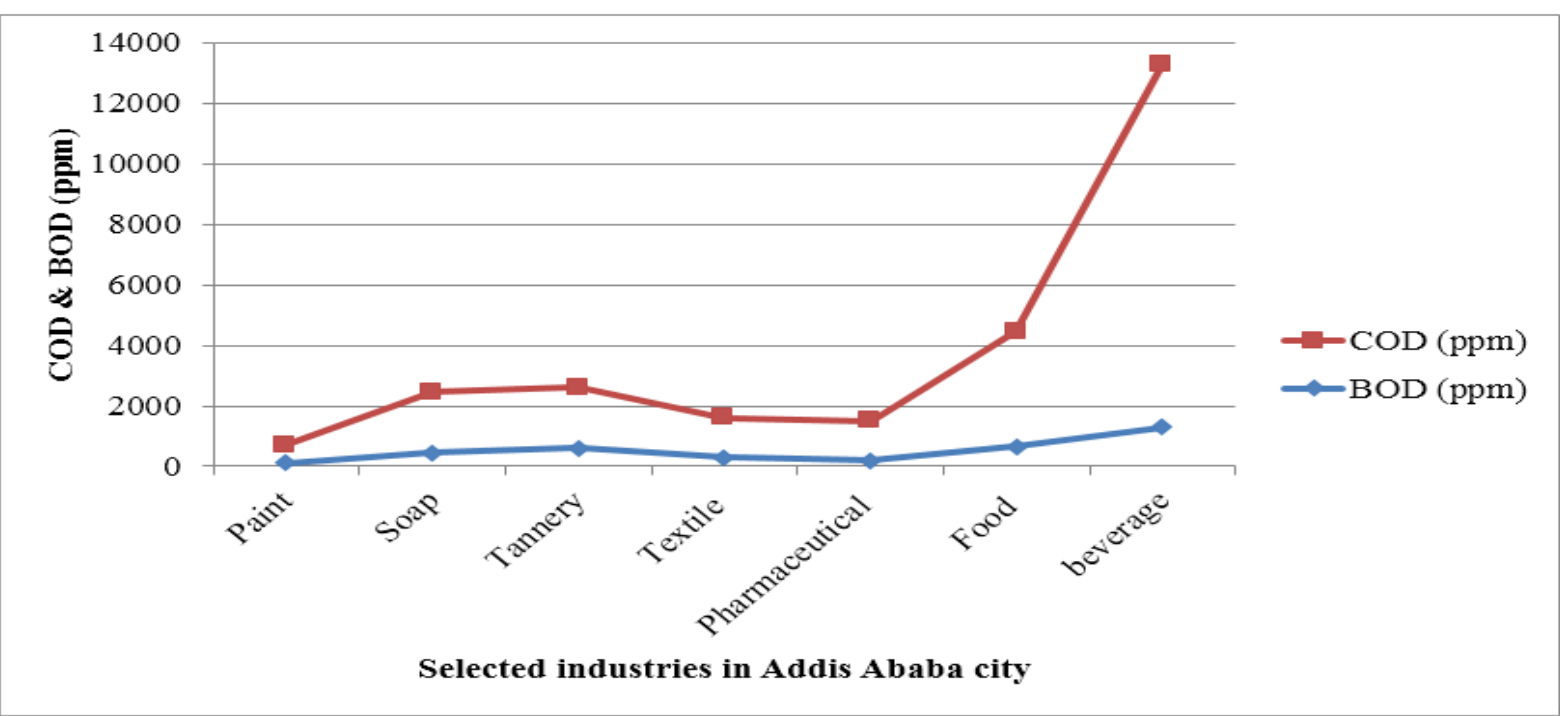

Figure 1. Chemical Oxygen Demand (COD) and Biological Oxygen Demand (BOD) in ppm for selected industries in Addis Ababa city. Source (Benti et al., 2016).

\section{Climate change and variabilities on fishery production and its value chain}

The fish subsector is very important for the food and livelihood security of many households and for export earnings. Worldwide, around two hundred million people are directly or indirectly working along the value chain of fish (FAO, 2018). In Ethiopia, the fishery sub-sector comes completely from inland water bodies such as rivers and lakes which contributing to socio-economic importance for the people in the country. Ethiopian people are directly or indirectly employed in the fishery industry either on a full-time, part-time or infrequent basis, and fish is used as the main source of protein supply for people in the country, predominantly those who exist in the neighborhood of water bodies such as lakes under Rift Valley areas, rivers in Gambela region, in the southwest, and Lake Tana. A value chain is the full range of activities that are required to bring a product or service from the beginning, through different phases of production, distribution to final consumers, and final discarding after uses (Kaplinsky and Morris 2001) and it can be used to study the complex networking of productions and trade including the fisheries sector. Since Ethiopia is a landlocked country, its fish demand is basically dependent on the capture fishery, however, the aquaculture sector is insignificant compared with capture fisheries (Hayelom and Eyob, 2021) and it contributes $0.2 \%$ of the total production of the country (FAOSTAT, 2020).

Climate change is estimated to alter aquatic food prices, by affecting the availability of aquatic resources and the global supply including the cost of goods, infrastructure, and services that are required in aquatic food production, processing, and distribution services(FAO, 2018). Climate change with increasing temperature may cause thermal stress in aquatic animals and this leads to reduce growth (Harvell et al. 2002). Climate changes impact on fisheries through factors such as changes in temperature, precipitation and oceanographic variables having significant ecological and biological changes on freshwater with fish pollutions (Cheung et al. 2009, Brander K. 2009) and this directly impacts peoples whose livelihoods depend on those ecosystems. For example, in Ethiopia, particularly in Lake Chamo, there is consistently climate change. From the metrological data, there has been a change in the pattern of the climate variables in Lake Chamowith with the increments of the mean annual temperature and reductions of the total rainfall (Berhan et al., 2020). This means that, the trend analysis of temperature and rainfall data, recorded over 20 years (1997-2016), indicated that, there was an increase of mean annual maximum temperature over the years, and the last class (2011-2016) being the hottest with a value of $31.224{ }^{\circ} \mathrm{C}($ Berhan et al. 2020). Now a day, there is a dramatic reduction of fish catchments or productions around Lake Chamo, and its future prediction indicated also going to be reduced (Berhan et al., 2020).In addition to anthropogenic activities, temperature and rainfalls are the major variables that can be indicated the existence of comparatively uncommon climate conditions.

\section{Implementations and mitigations of Environmental pollution in Ethiopia}

Increasing industrialization has a direct relationship with environmental pollutions. In Ethiopia, environmental degradation is derived due to high population growth, high urbanization rates, and increasing of the agricultural system, and the expansion of infrastructures. In Ethiopia, there is a growing and establishment of new industrialization, which is called an industrial park, and this indication of positive investment could have a capacity for the increasing of economic growth of the country and this help to transfer the country from farming to an industrialized economy. Therefore, this gigantic project needs a critical strategy that solves the environmental- 
related problem in the country (Pierre and Wondwosen, 2016). Ethiopia has a number of policies and strategies that pointed out the increasing the adaptive capacity and decreasing the susceptibility of the country's variability and change. However, Ethiopian government programs for investment framework for sustainable land management, while the cost and ability consequences of climate change have yet to be assembled into this. In the country, among the areas which are the most susceptible to drought, the National adaptation program of action improves that; agriculture was identified as the most vulnerable sector for drought in terms of livelihood, smallscale rain-fed subsistence farmers, and pastoralist incomes are found at risk (NAPA, 2007). Worldwide, carbon trading is the best mechanism for climate change mitigations. The most effective ways used to reducing or used as a mechanism of protection climate change and declining atmospheric greenhouse gases includes changing agricultural practices and improving land uses.

\section{Conclusions}

Ethiopia is one of the most water-rich countries in eastern Africa. In Ethiopia, inland water bodies are the main source of fish, and the capture fishery contributes the greatest potential (99.9\%) of fish supply. The fishery sector is one of the potential for increasing food security and as a source of income for the households in the country. However, the fishery is significantly affected due to different globally or natural and anthropogenic ways which affect the aquatic ecosystem. Even though there are disruptions of water quality in the high land areas of the country. However, the water quality problem is highly threatened under the central Rift valley areas. The existing environmental pollution which brings due to the effects of climate change, significantly changed the biography of fish stock and their relative abundance. In addition to climate changes as a factor for environmental pollutions, fish contamination, fish spoilage, and unhygienic handling and processing at landing sites with (30-40\%) postharvest losses also affected the fishery sector which causes environmental pollutions in the country. Chemicals used by horticulture and floriculture affected the water qualities of Lakes under down streams and the aquatic ecosystem. Under Rift valley areas, banned chemical pesticides with above permissible levels are used for the agricultural systems. Problems of sanitation and wastewater infrastructures, urbanization around Addis Ababa, capital of Ethiopia, and industrial effluents with toxic elements caused environmental pollutions which leads to water quality problems under the Rift valley water bodies. However, 90\% of industries in Addis Ababa simply discharged their wastes into the streams without any treatments, and $92.8 \%$ of the liquid waste is mixed with river and rainwater channels, and this affected the water quality and indirectly it affected the fishery sector. Organic pollutants which reduced the level of oxygen cause of the death animals species such as fish in water bodies.

\section{References}

Abraha Gebrekidan Asgedom1., Mulu Berhe Desta., and YirgaalemWeldegebrielGebremedhinAbraha et al (2012).Bioaccumulation of Heavy Metals in Fishes of Hashenge Lake, Tigray, Northern Highlands of Ethiopia. American Journal of Chemistry 2012, 2(6): 326-334 DOI: 10. 5923/j.chemistry.20120206.06.

Abera L, Getahun A, Lemma B. (2018). Changes in Fish Diversity and Fisheries in Ziway-Shala Basin: The Case of Lake Ziway,bEthiopia. Journal of Fisheries \& Livestock Production 6: 1-7.

Abong'o DA, Wandiga SO, Jumba IO, Van den Brink PJ, Naziriwo BB, Madadi VO, Wafula GA, Nkedi-Kizza P, Kylin H. (2015). Occurrence, abundance and distribution of benthic macroinvertebrates in the Nyando River catchment, Kenya. African Journal of Aquatic Science40: 373-392. https://doi. org/10.2989/16085914.2015.1113397.

Abrehet KM, Shewit G, Belayneh A (2015). Effects of Bahir Dar Textile Factory Effluents on the Water Quality of the Head Waters of Blue Nile River. Ethiopia. International Journal of Environmental Analytical Chemistry $7 \mathrm{p}$.

Alemayehu, T. (2006).Heavy Metal Concentration in the Urban Environment of Addis Ababa, Ethiopia.Soil and Sediment Contamination: An International Journal, 15, 591-602.

Ali, AA; Elazein, EM; Alian, MA (2011).Investigation of heavy metals pollution in water, sediment and fish at Red Sea-Jeddah Coast- KSA at two different locations. J. Appl. Environ. Biol. Sci. 1(12):630-637.

Ali Kh, Saber A, El-Shafai, Farag A, Samhan, Wagdy KB. (2008). Effect of water pollution on expression of immune response genes of Soleaaegyptiaca in Lake Qarun. African Journal of Biotechnology 7(10):14181425.

Ansara-Ross TM, Wepener V, Van den Brink PJ, Ross MJ. 2012. Pesticides in South African fresh waters. African Journal of Aquatic Science37: 1-16. https://doi.org/10.2989/16085914.2012.666336.

Arntz WE, Gallardo VA, Gutierrez D, Isla E, Levin LA, MendoJ,et al. (2006). ElNiño and similar perturbation effects on the benthos of the Humboldt, California, and Benguela Current up welling ecosystems. Advancesin Geosciences ; 6:243-65.

Aschale, M., Sileshi, Y., Kelly-quinn, M., \& Hailu, D. (2016). Evaluation of potentially toxic element pollution in the benthic sediments of the water bodies of the city of Addis Ababa, Ethiopia. Biochemical Pharmacology, $4,4173-4183$. 
Asefa W, Beranu T (2015) Levels of Some Trace Metals in Fishes Tissues, Water and Sediment at Tendaho Water Reservoir, Afar Region, Ethiopia. J Environ Anal Toxicol 5: 313. doi:10.4172/2161-0525.1000313.

Assefa G (2010). Pesticide use in Ethiopia, Ministry of Agriculture.www.prrp-ethiopia.org/index.../6-2012-aprilworkshop?...pesticide-use.

Asmare E, Demissie S, Tewabe D (2016). Fisheries of Jemma and Wonchit Rivers: As a Means of Livelihood Diversification and its Challenges in North Shewa Zone, Ethiopia. Fish Aqua J 7: 182. doi:10.4172/21503508.1000182

Awoke T (2015). Fish species diversity in major river basins of Ethiopia: A review. World Journal of Fish and Marine Sciences 7(5):365-374

Awulachew SB, Yilma AD, Loulseged M, Loiskandl W, Ayana M, Alamirew T. (2007). Water Resources and Irrigation Development in Ethiopia. Working Paper 123. Colombo, Sri Lanka: International Water Management Institute.

Ayenew, T., \& Legesse, D. (2007). The changing face of the Ethiopian rift lakes and their environs: Call of the time. Lakes\& Reservoirs: Research \& Management, 12, 149-165

Baron JS, Poff NL, Angermeier PL, Dahm CN, Gleick PH, Hairston NG, Jackson RB, Johnston CA, Richter BD, Stenman AD. 2002. Meeting ecological and societal needs for freshwater. Ecological Applications12: 12471260. https://doi. org/10.1890/1051 0761(2002)012[1247:MEASNF]2.0.CO;2.

Beyene A, Addis T, Kifle D, Legesse W, Kloos H, Triest L. (2009). Comparative study of diatoms and macroinvertebrates as indicators of severe water pollution: Case study of the Kebena and Akaki rivers in Addis Ababa, Ethiopia. Ecological indicators 9: 381-392. https://doi.org/10.1016/j.ecolind.2008.05.001. Bird Life International. 2019. Country profile: Ethiopia. A.

Bekele J, Hussien D. (2015).Prevalence of Internal Parasites of Oreochromis niloticus and Clarias gariepinus Fish Species in Lake Ziway, Ethiopia. Journal of Aquaculture Research \&Development 6: 1-4.

Benti F., Yonas S., and Teshome S. (2016).Assessment of the Status of Industrial Waste Water Effluent for Selected Industries in Addis Ababa, Ethiopia.Journal of Natural Sciences Research.ISSN 2224-3186 (Paper) ISSN 2225-0921 (Online).

Berhan M. T., Amare H., Daniel A. W., Bernice S. S. and Paul J. V. B. (2016). Impacts of nutrients and pesticides from small- and large scale agriculture on the water quality of Lake Ziway, Ethiopia Environ SciPollutRes.DOI 10.1007/s11356-016-6714-1.

Brander K. Impacts of climate change on fisheries. Journal of Marine Systems 2009, in press, doi:10.1016/j.jmarsys.2008.12.015.

Bridges KW, McClatchey WC (2009). Living on the margin: ethnoecological insights from Marshall Islanders at Rongelap atoll. Global Environmental Change;19 (2):140-6.

Castro-González, M. I., \& Méndez-Armenta, M. (2008). Heavy metals: Implications associated to fish consumption. Environmental Toxicology and Pharmacology, 26, 263-271.

Cheung WWL, Lam VWY, Sarmiento JL, Kearney K, Watson R, Pauly D (2008).Projecting global marine biodiversity impacts under climate change scenario.Fish and Fisheries; 2009, DOI 10.1111/j.14672979.2008.00315.x.

Cheung WWL, CloseC, Lam VWY, Watson R, Pauly D (2008). Application of macro ecological theory to predict effects of climate change on global fisheries potential. Marine Ecology Progress Series;365 : 187-97.

Central Stastical Agency (CSA). (2007). 2007 Population and Housing Census of Ethiopia: Administrative Report.

Central Stastical Agency (CSA). (2013). Report on Large and Medium Scale Manufacturing and Electricity Industry Survey. Addis Ababa.

Central Stastical Agency (CSA) (2012). Statistical report on area and production of crops and farm management practices, Central Statistical Agency, statistical bulletin 532, Addis Ababa.

Danquah L. (2010). The causes and health effects of river pollution: A case study of the Aboabo River, Kumasi.

Dereje T. (2014). Spatial and temporal distributions and some biological aspects of commercially important fish species of Lake Tana, Ethiopia. J Coastal Life Med. ;2(8): 589-595

DugasaG. and EndaleT. (2018).Determination of Some Selected Heavy Metals in Water, Oreochromis Niloticus and Labeobarbus Intermedius Samples from Abaya and Chamo Lakes. World Journal of Fish and Marine Sciences 10 (6): 01-11, 2018. ISSN 2078-4589DOI: 10.5829/idosi.wjfms.2018.01.11

Edwards-Jones, G., Plassmann, K. and Harris, I.M. (2009). Carbon foot printing of lamb and beef production systems: Insights from an empirical analysis of farms in Wales, UK. Journal of Agricultural Sciences, 147: 707-719.

Estifanos KT. (2008) Integrated assessment of ecosystem services and stakeholder analysis of Abiyata-Shalla Lakes national park, Ethiopia.mMSc Thesis in Environmental Sciences. Wageningen University.

Food and Agricultural Organization (FAO) (2016a). FAOSTAT. Database.Available at http:/faostat3.fao.org/browse/R/RP/E Accessed July 2016.Rome, Food and Agriculture Organization of the UnitedNations (FAO). 
Food and Agriculture Organization of the United Nations , FAO (2011). Fishery and aquaculture country profiles Ethiopia, http://www.fao.org/fishery/countrysector/FI-CP ET/en.

FAOSTAT (2020). Capture fishery and Aquaculture production in Ethiopia.

FuadA.andGelaneh WM. (2017).Determination of heavy metals concentrations within the ever growing Lake Baseka, Ethiopia using spectrophotometric technique.African Journal of Environmental Science and Technology.Vol. 11(3), pp. 146-150, March 2017.DOI: 10.5897/AJEST2016.2225 Article Number: 44A7D1E63034 ISSN 1996-0786.

Gashaw T. Matthias W.(2014). The state of inland fisheries in Ethiopia: a synopsis with updated estimates of potential yield.

Goraw Goshu, A.A. Koelmans and J.J.M. de Klein (2017).Water quality of Lake Tana basin, Upper Blue Nile, Ethiopia.A Review of Available Data. (C) Springer International Publishing Switzerland 2017. K. Stave et al. (eds.), Social and Ecological System Dynamics, AESS Interdisciplinary Environmental Studies and Sciences Series, DOI 10.1007/978-3-319-45755-0 10

Gudeta, D. T. (2012).Socio-economic and Environmental Impact of Floriculture Industry in Ethiopia, 155.Retrieved from http://lib.ugent.be/fulltxt/RUG01/001/894/550/RUG01-001894550_2012_0001_AC.pdf.

Gure, A; Kedir, K; Aburo, F (2019). Heavy Metal Concentrations in Fish Tissues from Gilgel Gibe (I) Hydroelectric Dam Reservoir, Ethiopia. Journal of Applied Science and Environmental management. Vol. 23 (8) 1411-1416 August 2019.

Harvell, C. D., Mitchell, C. E., Ward, J. R., Altizer, S., Dobson, A. P., Ostfeld, R. S \& Samuel, M.D. 2002. Climate warming and disease risks for terrestrial and marine biota, Science, 296, 5576, 2158-2162.

Hayelom Berhe and Eyob Bezabih (2021). Understanding fisheries'Contribution for food and nutrition security in Ethiopia: A review study; Global Scientific Journal, Volume 9, Issue 4, April 2021, Online: ISSN 2320-9186, www.globalscientificjournal.com.

Henry F, Amara R, Courcot L, Lacouture D, Bertho ML. Heavy metals in four fish species from the French coast of the Eastern English Channel and Southern Bight of the North Sea. Environ Int 2004;30:675-83.

Hirpo LA. (2016). Current status and trends of fishes and fishery of a shallow rift valley lake, Lake Ziway, Ethiopia.PhD thesis, AddisnAbaba University, Ethiopia.

International network of basin organization, Office national de l'eau et des milleuxaqutiques (ONEMA) International office for water, global water for partnership (2015). The hand book for management and restoration of aquatic ecosystems in river and lake basins. www.basins-management-publications.org

Janko A (2013). Assessment of fish products demand in some water bodies of Oromia, Ethiopia.International Journal of Agricultural Science 3(8):628-632.

Janko A (2014). Fish Production, Consumption and Management in Ethiopia. International Journal of Economics and Management 3:183.

Jansen, H. C., \&Harmsen, J. (2010).Pesticide monitoring in the Central Rift Valley 2009 -2010.

Jansen HC, Harmsen J (2011). Pesticide monitoring in the Central Rift Valley 2009-2010. Report 2083.Alterra,Wageningen, http://library. wur.nl/WebQuery/clc/1966024.

Kebede A, Meko T, Hussein A, Tamiru Y. (2017) BReview on Opportunities and Constraints of Fishery in Ethiopia. Int J Poul Page 3 of Fish Sci .1(1):1-8. DOI: 10.15226/2578-1898/1/1/00104

Larissa D., Mesfin M., Elias D., Carlos EV., Sven S. (2012). Assessment of heavy metals in water samples and tissues of edible fish species from Awassa and Koka Rift Valley Lakes, Ethiopia Article in Environmental Monitoring and Assessment · Environ Monit Assess DOI 10.1007/s10661-012-2777-8.

Maltby L, Van den Brink PJ, Faber JH, Marshall S.( 2018). Advantages and challenges associated with implementing an ecosystem services approach to ecological risk assessment for chemicals. Science of the Total Environment621: 1342-1351. https://doi.org/10.1016/j.scitotenv.2017.10.094.

MaschalTarekegn M, Truye AZ. (2018). Causes and impacts of shankila river water pollution in Addis Ababa, Ethiopia. Environ Risk Assess Remediat. ;2(4):21-30.

McSweeney C, Lizcano G, New M, Lu X .(2010). The UNDP Climate Change Country Profiles.Available via http://journals. ametsoc.org/doi/abs/10.1175/2009BAMS2826.1. Accessed on 10, May 2015.

Melaku, S., Wondimu, T., Dams, R., \&Moens, L. (2004). Simultaneous Determination of Trace Elements in Tinishu Akaki River Water Sample, Ethiopia, by ICP-MS. Can. J. Anal. Sci. Spectros., 49, 374-384.

Mekonnen, K. N., Ambushe, A. A., Chandravanshi, B. S., \&Redi-Abshiro, M. (2014).Assessment of potentially toxic elements in Swiss chard and sediments of Akaki River, Ethiopia. Toxicological and Environmental Chemistry, 96, 1501-1515.

Mesfin M T., Carlos Eduardo V. C., Elias D., and Sindern S. (2012). Assessment of heavy metals in water samples and tissues of edible fish species from Awassa and Koka Rift Valley Lakes, Ethiopia. Environmental Monitoring and Assessment · July 2012 DOI: 10.1007/s10661-012-2777-8 •

National Meteorological Agency (NMA) (2007). National Meteorology Agency: Final Report on Evaluation Criteria for Identifying High Priority Adaptation Activities prepared by B and M Development Consultants 
for NMA. Addis Ababa, Ethiopia.

National Meteorological Agency (NMA) (2001). Initial National Communication of Ethiopia to the United Nations Framework Convention on Climate Change, Addis Ababa: NMSA

NAPA (2007). Climate Change, National Adaptation Programme of Action Ethiopia. Addis Ababa

Ogutu-Ohwayo R, Hecky RE, Cohen AS, Kaufman L (1997). Human impacts on the African Great Lakes. Environmental Biology of Fishes ;50(2):117-131.

Olson E. (2004). Grading Drinking water in U.S cities what's on Tap? National resource defense Counsel, New York City, and Washington, D.C., Los Angeles, and San Francisco.

Population Census Commission (PCC ) (2008). Summary and Statistical Report of the 2007 Population and Housing Census: Population Size by Age and Sex. PCC, FDRE Addis Abeba, Ethiopia.

Pretty J, Toulmin C, Williams S (2011) Sustainable intensification in African agriculture.Int J Agric Sustain 9:524.

Pierre F. and Wondwosen S. (2016). Assessment of the Environment Pollution and its impact on Economic Cooperation and Integration Initiatives of the IGAD Region; National Environment Pollution Report Ethiopia, https://www.researchgate.net/publication/299442460, Research gate

PHRD (2015). List of Registered Pesticides as of June 2015. Ministry of Agriculture Plant Health Regulatory Directorate.

http://www.moa.gov.et/documents/93665/4536019/List+of+Registered+Pesticides+as+of+Jun Ethiopia. e+\%2C\%202015-.pdf/34309f8f-f790-4119-ac55-5d0b52a52ff2

Ramamohana Reddy ReddyAppannagari.(2017). Environmental pollution causes and consequences: a study. North Asian International Research Journal of Social Science \& Humanities ISSN: 2454-9827 Vol. 3, Issue 8, Aug. 2017.

Taddese A, Asferachew A (2008) An assessment of pesticide use: pesticides and hazards in the Ethiopian rift valley. Africa Stock Piles Programme.Institute for Sustainable Development and Pesticide Action network, UK. http://www.thenrgroup.net/theme/ PAN-ecotox/pdf/annex 6 ethiopia mini-project report.pdf.

Teklu BM, et al. (2014).Surface water risk assessment of pesticides in Ethiopia, Sci Total Environ (2014), http://dx.doi.org/ 10.1016/j.scitotenv.11.049.

Teklu BM, Adriaanse PI, Van den Brink PJ. (2016). Monitoring and risk assessment of pesticides in irrigation systems in Debra Zeit, Ethiopia. Chemosphere161: 280-291. https://doi.org/10.1016/j. chemosphere.07.031.

World fish center, policy brief (2007). The threat to fisheries and aquaculture from climate change, World fish Center, policy brief, 2007

Tüzen, M (2003).Determination of heavy metals in fish samples of the middle Black Sea (Turkey) by graphite furnace atomic adsorption spectrometry. Food Chem. 80(1): 119-123.

SEI,IUCN,IISD. (2003). Intercooperation Livelihoods and climate change: combining disaster risk reduction, natural resource management and climate change adaptation in a new approach to the reduction of vulnerability and poverty. Accessed 10/05/04. Available from:/http://iisd.org/ publications/ publication. asp? pno $=529 \mathrm{~S}$

UNDP Ethiopia (2011). Framework for UNDP Ethiopia's Climate Change, Environment, and Disaster Risk Management Portfolio.

UNEP (2016). A snapshot of the world's water quality: towards a global assessment. Nairobi, United Nations Environment Programme (UNEP).

WSA (2010). Cities without Slum; Situation Analysis of Informal Settlements in Addis-Ababa, A Slum upgrading program United Nations Human Settlements Program Nairobi, Kenya.

Yared BY. Yoshinori I.., Shouta M.M. Nakayama., AksornS., Kensuke W., Mayumi I. (2013). Organochlorine pesticides and heavy metals in fish from Lake Awassa, Ethiopia: Insights from stable isotope analysis. Chemosphere 91 (2013) 857-863. Journal homepage: www.elsevier.com/locate/chemosphere.

Yohannes G. and Mebratu K. (2009). Local innovation in climate-change adaptation by Ethiopian pastoralists: PROLINNOVA-Ethiopia and Pastoralist Forum Ethiopia (PFE), Final report. Addis Ababa, Ethiopia.

ZinabuG.andZerehun D. (2002). The chemical composition of the effluent from Awasa Textile Factory and its effects on aquatic biota. SINET: Ethiop. J. Sci., 25, 263-274 